\title{
Evaluation of biological monitoring markers using genomic and proteomic analysis for automobile emission inspectors and waste incinerating workers exposed to polycyclic aromatic hydrocarbons or $2,3,7,8$,-tetracholrodedibenzo-p-dioxins
}

\author{
Meyoung Kon $\mathrm{Kim}^{1}$, Sangnam $\mathrm{Oh}^{2}$, \\ Ji Hye Lee ${ }^{1}$, Hosub Im $^{3}$, Yeon Mi Ryu ${ }^{1}$, \\ Eunha $\mathrm{Oh}^{3}$, Joohyun Lee ${ }^{3}$, Eunil Lee \\ and Donggeun Sul ${ }^{5,6}$ \\ ${ }^{1}$ Department of Biochemistry and Molecular Biology \\ School of Medicine \\ ${ }^{2}$ Graduate School of Biotechnology \\ ${ }^{3}$ School of Public Health \\ ${ }^{4}$ Department of Preventive Medicine \\ School of Medicine and Institute for Environmental Health \\ Medical Science Research Center \\ ${ }^{5}$ Environmental Toxico-Genomic and Proteomic Center \\ School of Medicine, Korea University \\ Anamdong 5-ga, Sungbuk-gu, Seoul 136-705, Korea \\ ${ }^{6}$ Corresponding author: Tel, 82-2-922-6174; \\ Fax, 82-2-927-7220; E-mail, dsul@korea.ac.kr
}

Accepted 18 August 2004

Abbreviations: 1-OHP, 1-hydroxy pyrene; 2-DE, second dimensional electrophoresis; GC/MS, gas chromatography/mass spectrometry; HPLC, High performance liquids chromatography; PAHs, polycyclic aromatic hydrocarbons

\begin{abstract}
In this study, we investigated the effects of PAHs and dioxin on mRNA and plasma protein expression using genomic and proteomic analysis for automobile emission inspectors and waste incineration workers. About 54 workers from automobile emission inspection offices, 31 workers from waste incinerating company and 84 unexposed healthy subjects were enrolled in this study. Urine and air samples were collected and analyzed by HPLC and GC/MS. Comet assays were carried out to evaluate any DNA damage in mononuclear and polynuclear cells. A significant difference in Olive tail moments in mononuclear cells was observed between exposed and control subjects $(P<0.0001)$. To examine the differences of the gene expression
\end{abstract}

profile in automobile emission inspectors and waste incineration workers, radioactive complementary DNA microarrays were used to evaluate changes in the expression of 1,152 total genes. The gene expression profiles showed that 11 genes were up-regulated and 4 genes were down-regulated in waste incinerating workers as compared with controls. Plasma proteins were analyzed by 2-dimentional electrophoresis with pH 3-10 NL IPG Dry strip. The protein expression profiles showed that 8 proteins were upregulated and 1 protein, haptoglobin, was downregulated in automobile emission inspectors and waste incineration workers. Serum paraoxonase/ arylesterase was found only in the plasma of waste incineration workers. The expression of genes and proteins involved in oxidative stress were up-regulated in both automobile emission inspectors and waste incineration workers. Several proteins, such as transthyrethin, sarcolectin and haptoglobin, that were highly up- or down-regulated, could serve as biological monitoring markers for future study.

Keywords: biological monitoring markers; dioxins; genomic; polycyclic aromatic hydrocarbons; proteomic

\section{Introduction}

Environmental pollutants that cause genotoxic, immunotoxic, and neurotoxic effects in animal and human have been found and studied to determine the role of toxicity and to search for monitoring methods for pre-diagnosis or the prevention of disease (Albertini et al., 1998; Shugart et al., 1998; Burchiel et al., 1999; Claudio et al., 2000; Chhabra et al., 2003). Even though there are many toxic environmental compounds that have been studied, polycyclic aromatic hydrocarbons and dioxins are frequently focused on as environmental genetic toxicants and endocrine disruptors (Kogevinas, 2001; Their et al., 2002; Birnbaum et al., 2003; Hosokawa et al., 2003; Oh et al., 2003).

Dioxins are known as the most toxic compounds 
that man has ever made. They are generally thought of as an industrial problem because they are formed as the by-products of chlorine-containing manufacturing processes or from incineration (Everert and Baeyens, 2002; Birnbaum et al., 2003; Hays and Aylward, 2003). Therefore, incineration workers have usually been chosen to evaluate the toxic effects of dioxin in humans (Kumagai et al., 2003). However the incineration workers generally are exposed to another toxic component, PAHs which are a class of stable organic molecules made up of carbon and hydrogen. They are ubiquitous environmental pollutants of air, water and soil produced as consequence of the incomplete combustion of organic materials (Brandt and Watson, 2003). Residential heating source, refuse burning and vehicle exhausts also currently contribute to the widespread distribution of PAHs (Diaz-Sanchez, 1997). The International Agency for Research on Cancer has characterized PAHs as carcinogens (IARC, 1998).

These two major environmental toxic components are found to cause DNA damage as well as changes in the genes controlling protein expression or cell growth and differentiation (Kress and Greenlee, 1997; Mann et al., 1999; Melendez-Colon et al., 1999; Wu et al., 2001). Genomic analysis has recently been used as an approach to analyze differential gene expression and moreover, proteomics has been found to be a powerful method to elucidate cellular response to toxic compounds at the protein level. This new method is done by comparing the 2-dimensional electrophoresis patterns of proteomes under different conditions after exposure to compounds of toxicological relevance (Moller et al., 2001). A large range of immobilized $\mathrm{pH}$ gradients (IPG) strips and more advanced two-electrophoresis analysis makes it possible to identify a number of proteins whose level significantly increased or decreased in those cells and animals responding to environmental challenges after treatment with toxic compounds (Joo et al., 2003; Son et al., 2003).

Unfortunately there have been no studies reported concerning the gene and protein expressions in human occupationally exposed to these two toxic compounds. We proposed it would be of valuable to determine the changes of mRNA in blood cells and plasma protein expression for the roles of biological monitoring markers in workers exposed to PAHs or dioxins. It is known that mRNA and their expressed proteins cause DNA damage or DNA adducts which induce the changes in genes controlling further protein expression.

In present study, we chose two occupational groups, emission inspectors and waste incineration workers, who are exposed to PAHs or dioxin; emission inspectors are routinely exposed to $\mathrm{PAHs}$ and inci- neration workers are exposed to PAHs and dioxins together. Therefore, the only way to evaluate the toxic effects of dioxin or to find a specific biological monitoring marker for dioxin is to compare gene or protein expressions in theses two subject groups on the blood cells and plasma proteins using genomic and proteomic analysis. We present here results of the study showing new biological monitoring markers in two different fields, that is, genomics and proteomics.

\section{Materials and Methods}

\section{Subjects}

Forty four workers from three automobile emission inspection offices in Seoul, 31 workers from an incineration company in Ansan, and 84 unexposed healthy donors who had undergone an annual health examination at Soonchunhyang University Hospital in Seoul, South Korea from May 5 to June 6, 2002 were enrolled in our study. All subjects completed a questionnaire, which included items on smoking, drinking, age, medication, etc. All workers were recruited at two companies in March 14 and July 28, 2002 and these workers had been exposed to vehicle exhaust and refuse burning fumes containing PAHs or dioxin. All workers and control subjects had not eaten any grilled and smoked meats within the last $48 \mathrm{~h}$.

\section{Sample preparation}

Blood samples, 4-5 $\mathrm{ml}$ of heparinized whole blood, were collected by veinpuncture from each human subject. Two milliliters of whole blood were mixed with same volume of PBS solution, and mononuclear and polynuclear cells were separated using gradient 1.077 and 1.109 gradient Ficoll Paque solution for Comet assay. The human blood plasma and the buffy coat containing white blood cells were isolated from the remaining whole blood by centrifugation $(1,000 \mathrm{~g}, 5$ $\mathrm{min})$ and then this was aliquoted and frozen at $-80^{\circ} \mathrm{C}$ until analysis.

Frozen plasma was thawed on ice. For the plasma sample preparation, 12.5 ul plasma were diluted 20 times in a reducing, denaturing solution (sample buffer) containing $7 \mathrm{M}$ urea, $2 \mathrm{M}$ thiourea, $4 \%$ CHAPS, $40 \mathrm{mM}$ tris $(\mathrm{pH} 8.5), 65 \mathrm{mM}$ DTT, $0.5 \%$ IPG buffer, $1 \mathrm{mM}$ EDTA, and protease inhibitor cocktail mixture. In order to desalt and clean the denatured plasma samples, the molecular cut off column (microcon-3, Milipore) was used and centrifuged $(10,000 \mathrm{~g}, 30 \mathrm{~min})$ with loaded samples. Protein samples were determined by a slightly modified Bradford assay. 


\section{Determination of 1-0H-pyrene, 2-naphthol and creatinine in urine}

Urinary 1-OHP was analyzed according to the method developed by Jongeneelen et al. (2001). Ten milliliter of urine sample was adjusted to the $\mathrm{pH} 5.0$ with 1 $\mathrm{M} \mathrm{HCl}$ and $0.1 \mathrm{M}$ acetate buffer $\mathrm{pH} 5.0$ was added to a volume of $30 \mathrm{ml}$. The mixture was hydrolyzed enzymatically with $12.5 \mu \mathrm{l}$ of $\beta$-glucuronidase/arylsulphatase at $37^{\circ} \mathrm{C}$ for $16 \mathrm{~h}$. Afterwards, the hydrolyzed urine sample was applied to $\mathrm{C} 18$ reverse-phase cartridge (Alltech Associate Inc., IL), which had been washed with $5 \mathrm{ml}$ of methanol followed by $10 \mathrm{ml}$ of distilled water. The hydrolyzed sample was passed through the cartridge and it was followed by $8 \mathrm{ml}$ of water. The retained solutes were eluted with $10 \mathrm{ml}$ of methanol. The solvent was evaporated at $60^{\circ} \mathrm{C}$ under a gentle flow of nitrogen. The residues were resolved in methanol and $20 \mu \mathrm{l}$ of the sample was injected into a HPLC system (Gilson, France) with $250 \times 4.6 \mathrm{~mm}$ I.D. Xterra RP-18 (5 $\mu \mathrm{m})$ column (Waters, Milford, MA). 1-OHP was quantitatively determined by the use of a fluorescence detector (Shimadzu, RF-10AXL, Japan), with excitation and emission wavelengths of 242 and $388 \mathrm{~nm}$, respectively. Urinary 2-naphthol was analyzed according to the method of Kim et al. (1999). Three milliliter of urine samples were buffered with $300 \mu \mathrm{l}$ of $0.2 \mathrm{M}$ sodium acetate buffer $(\mathrm{pH} 5.0)$, and then hydrolyzed enzymatically with $30 \mu \mathrm{l}$ of $\beta$-glucuronidase and sulfatase (Sigma Co. St. Louis, MO), for $16 \mathrm{~h}$ at $37^{\circ} \mathrm{C}$ in a shaking water bath. After hydrolysis, $5 \mathrm{ml}$ of acetonitrile was added and centrifuged at $1000 \mathrm{~g}$ for $10 \mathrm{~min}$. A $20 \mu \mathrm{l}$ of the supernatant was injected into the HPLC system. A standard stock solution of 2naphthol was prepared by dissolving 2-naphthol (Sigma Co. St. Louis, MO) in acetonitrile (Merck Co. Damstadt, Germany). The urinary creatinine was determined with a Hitachi 747 Computer-Directed Analyzer.

\section{Analysis of PAHs and dioxin in air}

PAHs were analyzed according to the NIOSH method 5515. PAHs were collected by using personal sampler from the breathing zones of both workers in the automobile emission inspection and waste incinerating companies. Particle compounds were collected with $37 \mathrm{~mm}$ PTFE filter (Gelman), which was followed by a glass absorbent tube containing XAD-2 resins (SKC inc.). The air flow rate was $1.7 \mathrm{l} / \mathrm{min}$. Sixteen authentic standards of PAH were obtained from Supelco company to analyze PAH collected by personal samplers. PAHs were extracted from the PTFE filters and XAD-2 absorbent materials by sonication for $30 \mathrm{~min}$ with $1 \mathrm{ml}$ of dichloromethane and acetonitrile. GC-MS analysis was performed with an Agilent 6890 series
GC equipped with a HP-5 column (Agilent). The GC was interfaced to a high resolution Agilent $5973 \mathrm{MS}$. A HP-5 column (length $30 \mathrm{~m} \times 0.32 \mathrm{~mm}$ I.D.) was employed with helium as carrier gas. The GC temperature was programmed as follows: first $100^{\circ} \mathrm{C}$ for $5 \mathrm{~min}$, then from $100^{\circ} \mathrm{C}$ to $290^{\circ} \mathrm{C}$ at $5^{\circ} \mathrm{C} / \mathrm{min}$ and finally $290^{\circ} \mathrm{C}$ for $10 \mathrm{~min}$. The injector and detector temperatures were 200 and $250^{\circ} \mathrm{C}$, respectively. PAHs were identified according to their elemental composition, mass of their molecular ions, and by comparing with fragmentation patterns obtained from authentic standards. Analysis of dioxin was according to modified EPA method (Method 23A). Gaseous and particulate dioxin like compounds were collected in a multicomponent sampling train at three times from June 14 to July 18, 2002. The collection material was extracted using acetone, methylene chloride and toluene (Merck Co. Darmstadt, Germany). The samples were then spiked with $15{ }^{13} \mathrm{C}_{12}$-labelled-PCDD/F prior to extraction and analyzed with a high resolution gas chromatographic column coupled a high resolution mass spectrometer (HRGC/HRMS).

\section{Comet assay}

The comet assay was performed according to Singh with minor modifications (Singh et al., 1988). Normal melting point agarose (Ameresco, NMA) and low melting point agarose (Ameresco, LMA) were dissolved in PBS (Gibco BRL) using a microwave oven. In brief, $100 \mu \mathrm{l}$ of $1 \%$ NMA was added onto fully frosted slides precoated with $50 \mu$ of $1 \%$ NMA for the firm attachment and the slides were allowed to solidify with cover slips in the refrigerator for $5 \mathrm{~min}$. After solidification of the gel, the cover slips were removed and lymphocytes in $50 \mu \mathrm{l}$ were mixed with $50 \mu \mathrm{l}$ of $1 \%$ LMA. The cover slips were added on the layer and the slides were allowed to solidify in the refrigerator for $5 \mathrm{~min}$. After removing cover slips, $100 \mu \mathrm{l}$ of $0.5 \%$ LMA was added on the third layer and the slides were placed with cover slips again in the refrigerator for $5 \mathrm{~min}$. The slides were then submersed in the lysing solution $(2.5 \mathrm{M} \mathrm{NaCl}, 100$ mM EDTA-2Na, $10 \mathrm{mM}$ Tris- $\mathrm{HCl}$, $\mathrm{pH} 10 ; 1 \%$ Triton $\mathrm{X}-100$ and $10 \%$ DMSO, $\mathrm{pH}$ 10) for $1 \mathrm{~h}$. The slides were then placed in unwinding buffer (1 mM EDTA and $300 \mathrm{mM} \mathrm{NaOH}, \mathrm{pH}$ 13) for $20 \mathrm{~min}$ and electrophoresis was carried out using the same solution for $20 \mathrm{~min}$ at $25 \mathrm{~V}$ and $300 \mathrm{~mA}(0.8 \mathrm{~V} / \mathrm{cm})$. After electrophoresis, the slides were neutralized by washing three times with neutralization buffer $(400 \mathrm{mM}$ Tris- $\mathrm{HCl}, \mathrm{pH}$ 7.4) for $5 \mathrm{~min}$ each and were stained with $50 \mu \mathrm{l}$ of $10 \mu \mathrm{g} / \mathrm{ml}$ ethidium bromide. The slides were examined using a Komet 4.0 image analysis system (Kinetic Imaging, Liverpool, UK) fitted with an Olympus BX50 fluorescence microscope equipped 
with an excitation filter of $515-560 \mathrm{~nm}$ and a barrier filter of $590 \mathrm{~nm}$. For each treatment group, two slides were prepared and each 50 randomly chosen cells (total 100 cells) were scored manually. The Olive tail moment (=(Tail.mean - Head.mean) $\times$ Tail\%DNA/100) parameter was calculated automatically using the Komet 4.0 image analysis system.

\section{Human cDNA microarray}

A human cDNA microarray was primarily derived from a commercially available master set of approximately 15,000 human verified sequences (Research Genetics, Inc., Huntsville, AL). The 15,000-human cDNA clone set was sorted according to a list of genes $(1,152$ elements) representing families such as differentiation, development, proliferation, transformation, cell-cycle progression, immune response, transcription and translation factors, oncogenes, and molecules involved in cell growth and maintenance. PCR-amplified cDNAs were spotted on nylon membranes. The general methodology of arraying is based on the procedures of DeRisi et al. (1996).

\section{cDNA Radiolabeling}

The total RNAs prepared from the bloods samples of automobile emission inspectors, waste incineration workers, and control subjects were used to synthesize 33P-labeled cDNAs by reverse transcription. Briefly, 3-10 $\mu \mathrm{g}$ of RNA was labeled in a reverse transcription reaction mixture containing $5 \mathrm{x}$ first-strand PCR buffer, $1 \mu \mathrm{g}$ of 24 -mer poly dT primer, $4 \mu \mathrm{l}$ of $20 \mathrm{mM}$ each dNTP excluding dCTP, $4 \mu$ of $0.1 \mathrm{M}$ DTT, $40 \mathrm{U}$ of RNase inhibitor, and $6 \mu$ of 3,000 $\mathrm{Ci} / \mathrm{mmol} \alpha-{ }^{33} \mathrm{P}$ dCTP (a final volume of $40 \mu \mathrm{l}$ ). This mixture was heated at $65^{\circ} \mathrm{C}$ for $5 \mathrm{~min}$, followed by incubation at $42^{\circ} \mathrm{C}$ for $3 \mathrm{~min}$. Two $\mu \mathrm{l}$ (specific activity: $200,000 \mathrm{U} / \mathrm{ml}$ ) of Superscript II reverse transcriptase (Life Technologies, Inc., Rockville, MD) was then added and the samples were incubated for $30 \mathrm{~min}$ at $42^{\circ} \mathrm{C}$, followed by the addition of $2 \mu$ of Superscript II reverse transcriptase and another $30 \mathrm{~min}$ of incubation. Five $\mu \mathrm{l}$ of $0.5 \mathrm{M}$ EDTA was added to chelate the divalent cations. After the addition of 10 $\mu \mathrm{l}$ of $0.1 \mathrm{M} \mathrm{NaOH}$, the samples were incubated at $65^{\circ} \mathrm{C}$ for $30 \mathrm{~min}$ to hydrolyze the remaining RNA. Following the addition of $25 \mu \mathrm{l}$ of $1 \mathrm{M}$ Tris ( $\mathrm{pH} \mathrm{8.0)}$, the samples were purified using Bio-Rad 6 purification columns (Hercules, CA). This resulted in $5 \times 10^{6}$ to $3 \times 10^{7} \mathrm{cpm}$ per reaction (Vawter et al., 2001).

\section{Hybridization and Scanning}

cDNA microarrays were pre-hybridized in a hybridization buffer containing $4.0 \mathrm{ml}$ Microhyb (Research Genetics), $10 \mu \mathrm{l}$ of $10 \mathrm{mg} / \mathrm{ml}$ human Cot 1 DNA (Life
Technologies), and $10 \mu \mathrm{l}$ of $8 \mathrm{mg} / \mathrm{ml}$ poly $\mathrm{dA}$ (Pharmacia, Peapack, NJ). Both Cot 1 and poly $d A$ were denatured at $95^{\circ} \mathrm{C}$ for $5 \mathrm{~min}$ prior to use. After $4 \mathrm{~h}$ of prehybridization at $42^{\circ} \mathrm{C}$, approximately $10^{7} \mathrm{cpm} / \mathrm{ml}$ of heat-denatured $\left(95^{\circ} \mathrm{C}, 5 \mathrm{~min}\right)$ probes were added and the incubation continued for $17 \mathrm{~h}$ at $42^{\circ} \mathrm{C}$. The hybridized arrays were washed three times in $2 \mathrm{x}$ SSC and $0.1 \%$ SDS for $15 \mathrm{~min}$ at room temperature. The microarrays were exposed to phosphoimager screens for 1-5 days, and the screens were then scanned in a FLA-8000 (Fuji Photo Film Co., Japan) at $50-\mu \mathrm{m}$ resolution (Vawter et al., 2001).

\section{Genomic data analysis}

Microarray images were trimmed and rotated for further analysis using L-Processor (Fuji Photo Film Co., Japan). The gene expression of each microarray was captured by the intensity of each spot produced by radioactive isotopes. Pixels per spot were counted by Arrayguage (Fuji Photo Film Co.) and exported to Microsoft Excel (Microsoft, Seattle, WA). The data were normalized with $Z$ transformation to obtain $Z$ scores by subtracting each average of gene intensity and dividing with each standard deviation. Z scores provide each of 2,304-spotted (two sets of 1,152 genes) genes with the distance from the average intensity and were expressed in units of standard deviation. Thus, each $Z$ score provides flexibility to compare different sets of microarray experiments by adjusting differences in hybridization intensities. Gene expression difference as compared with untreated control cells was calculated by comparing $Z$ score differences ( $Z$ differences) among the same genes. This facilitates comparing each gene that had been up- or down-regulated as compared with the control cells. $Z$ differences were calculated first by subtracting $Z$ scores of the controls from each $Z$ score of the samples. These differences were normalized again to distribute their position by subtracting the average $Z$ difference and dividing with the standard deviation of the $Z$ differences. These distributions represent the $Z$ ratio value and provide the efficiency for comparing each microarray experiment (Vawter et al., 2001). Scatter plots of intensity values were produced by Spotfire (Spotfire, Inc., Cambridge, MA) (Tanaka et al., 2000). Cluster analysis was performed on the Z-transformed microarray data by using two programs available as shareware from Michael Eisen's laboratory (http://rana.lbl.gov). Clustering of changes in gene expression was determined by using a public domain cluster based on pair-wise complete-linkage cluster analysis (Eisen et al., 1998). 


\section{Two dimensional polyacrylamide gel electrophoresis (2DE-PAGE)}

2-DE was performed essentially as described by Hochstrasser et al. for standard plasma samples. In the first dimension of 2-DE, isoelectric focusing (IEF), the proteins were separated only according to their isoelectric points. The preparated protein sample solution (40 ug) was mixed with rehydration buffer (containing $8 \mathrm{M}$ urea, $2 \%$ CHAPS, $0.5 \%$ IPG buffer, 65 $\mathrm{mM}$ DTT, and a trace of bromophenol blue) up to 450 $\mathrm{ul}$ at total volume per one sample. IEF was carried out with commercially available immobilized $\mathrm{pH}$ gradients [nonlinear $\mathrm{pH}$ gradient 3-10 $(3-10 \mathrm{NL}), 24 \mathrm{~cm}$ ], using the IPGphor (Amersham Pharmacia Bioscience, Amersham, UK) apparatus. The gel was rehydrated in the presence of the sample for $10 \mathrm{~h}$ and focused for 81,500 Vhs. After IEF, the IPG gel strips were equilibrated twice for $15 \mathrm{~min}$, under gentle shaking at room temperature, first in solutions (equilibration buffer: $50 \mathrm{mM}$ Tris- $\mathrm{HCl}, \mathrm{pH}$ 8.8, $6 \mathrm{M}$ urea, $30 \%$ glycerol, $1 \% \mathrm{w} / \mathrm{v}$ SDS) containing $1 \%$ DTT and, next in equilibration buffer containing $2.5 \%$ iodoacetamide. In the second dimension, SDS-PAGE, the proteins were resolved solely on the basis of their molecular masses in $9-16 \% \mathrm{~T}$ gradient polyacrylamide gels using Ettan Dalt System (Amersham Pharmacia Bioscience). The IPG strips were embedded with $0.5 \% \mathrm{w} / \mathrm{v}$ melted agarose prior to the run on the SDS-PAGE slabs. The agarose contained $0.001 \%$ $\mathrm{w} / \mathrm{v}$ bromophenol blue as a tracking dye. Running conditions were $2.5 \mathrm{w} / \mathrm{gel}$ for $15 \mathrm{~min}$ and $140 \mathrm{w} /$ total for $6 \mathrm{~h}$ until the bromophenol blue reached the end of the gel.

\section{Visualization and image analysis}

After separation in SDS-PAGE gels, the proteins were visualized by a silver staining kit (Amersham Pharmacia Bioscience). The procedure was followed according to manufacture's instruction. The silver-stained gels were scanned and analyzed using Image analysis software (Amersham Pharmacia Bioscience).

\section{Protein identification}

Electrophoretically separated proteins were excised from the gels, washed with $100 \mu \mathrm{l}$ of $25 \mathrm{mM}$ $\mathrm{NH}_{4} \mathrm{HCO}_{3}$ and dehydrated with $100 \mu$ of acetonitrile. Reduction was performed by a $1 \mathrm{~h}$ reaction with 10 $\mathrm{mM}$ DTT at $57^{\circ} \mathrm{C}$ and alkylation was followed with 25 $\mathrm{mM}$ iodoacetamide for $45 \mathrm{~min}$ at room temperature. Protein digestion was performed with trypsin at $35^{\circ} \mathrm{C}$ overnight and the digested peptides were extracted twice with a solution of $50 \%$ acetonitrile $-25 \mathrm{mM} \mathrm{am}$ monium bicarbonate. The extracts were pooled and desalted with ZipTip C18 (Milipore Co. Bedford, MA).
Purified peptide fragments from the digested proteins were subjected to Perspective Biosystem MALDI-TOF voyager DE-STR Mass Spectrophotometer (Framingham, MA) with an internal calibration. The peptide mass fingerprint obtained from each protein digest was submitted to databases using the program MS-Fit (http://prospector.ucsf.edu/ucsf html4.01) in order to identify the proteins.

\section{Statistical analysis}

Statistic analyses were performed using SAS version 6.12. To test the significant differences among the three groups of automobile emission inspection workers, waste incineration workers, and control subjects, we used the analysis of variance (ANOVA) for the means of urinary 1-OH-pyrene, 2-naphthol, and olive tail moments of mononuclear and polynuclear cells. Duncan's multiple range test was used for multiple comparison of means after ANOVA when statistically significant difference was found.

\section{Results}

\section{Characteristics of subjects}

Table 1 shows the relevant subject characteristics, such as age and smoking habits. Age distribution did not show the same exact pattern between workers exposed to PAHs and control subjects. The mean of age for the automobile emission inspection and waste incineration workers and control subjects were 36.4 $\pm 6.6, \quad 37.7 \pm 8.6$ and $31.6 \pm 10.5$ years old, respectively. The age comparison for the exposed and control subjects did not show a significant difference $(P>0.290$ ANOVA). Smokers are more frequent among the workers exposed to PAHs than among the control subjects (Table 1). The number of cigarettes which automobile emission inspectors and waste incineration workers and control subjects smoked per day was $6.67,11.57$ and 7.67 respectively (Table 1).

\section{Determination of 1-OH-pyrene and 2-naphthol in urine}

Table 2 shows the urinary concentration of 1-OHP and 2-naphthol. The mean values of 1-OH-pyrene in automobile emission inspectors, waste incineration workers and control subjects were, $0.298 \pm 0.212$, $0.531 \pm 0.427$ and $0.061 \pm 0.094 \mathrm{umol} / \mathrm{mol}$ creatinine, respectively (Table 2 ). The mean values of 2-naphthol in automobile emission inspectors, waste incineration workers and control subjects were $5.894 \pm 4.683$, $8.947 \pm 5.931$ and $1.924 \pm 3.441 \mathrm{~mol} / \mathrm{mol}$ creatinine, respectively (Table 2). Waste incineration workers showed higher concentrations of 1-OHP and 2-na- 
Table 1. Characteristics of exposed and control subjects.

\begin{tabular}{|c|c|c|c|c|}
\hline & & $\begin{array}{c}\text { Automobile emission } \\
\text { inspection workers } \\
(N=44)\end{array}$ & $\begin{array}{c}\text { Waste incineration } \\
\text { workers } \\
(\mathrm{N}=31)\end{array}$ & $\begin{array}{l}\text { Control subjects } \\
\qquad(\mathrm{N}=84)\end{array}$ \\
\hline \multirow[t]{5}{*}{ Age (year old) } & $20-29$ & $1(2 \%)$ & $7(23 \%)$ & $49(58 \%)$ \\
\hline & $30-39$ & $36(67 \%)$ & $13(42 \%)$ & $21(25 \%)$ \\
\hline & $40-49$ & $17(31 \%)$ & $9(29 \%)$ & $8(10 \%)$ \\
\hline & $50<$ & & $2(6 \%)$ & $6(7 \%)$ \\
\hline & Mean age & 36.4 & 37.7 & 31.6 \\
\hline \multirow[t]{3}{*}{ Smoking } & Smoking & $26(59 \%)$ & $22(71 \%)$ & $31(37 \%)$ \\
\hline & Ex-smoking & $7(16 \%)$ & $5(16 \%)$ & $8(10 \%)$ \\
\hline & Non-smoking & $11(25 \%)$ & $4(13 \%)$ & $45(53 \%)$ \\
\hline \multirow[t]{2}{*}{ Drinking } & Drinking & $33(75 \%)$ & $31(100 \%)$ & $76(90 \%)$ \\
\hline & Non-drinking & $11(25 \%)$ & $0(0 \%)$ & $8(10 \%)$ \\
\hline
\end{tabular}

No medication treatment in all subjects.

Table 2. Levels of 1-OHP and 2-naphthol in automobile emission inspection workers, waste incineration workers and control subjects.

\begin{tabular}{|c|c|c|c|c|}
\hline & & $\begin{array}{l}\text { Automobile emission } \\
\text { inspection workers }\end{array}$ & $\begin{array}{l}\text { Waste incineration } \\
\text { workers }\end{array}$ & Control subjects \\
\hline Number & & 44 & 31 & 84 \\
\hline $\begin{array}{c}\text { 1-OHP } \\
(\mu \mathrm{mol} / \mathrm{mol} \text { creatinine })\end{array}$ & $\begin{array}{r}\mathrm{AM} \pm \mathrm{ASD} \\
\text { (Range) } \\
\mathrm{GM} \pm \mathrm{GSD}\end{array}$ & $\begin{array}{c}0.298 \pm 0.212^{\mathrm{bc}} \\
(0.000-1.012) \\
0.232 \pm 0.003\end{array}$ & $\begin{array}{l}0.531 \pm 0.427^{\mathrm{ac}} \\
(0.127-1.485) \\
0.405 \pm 0.002\end{array}$ & $\begin{array}{l}0.061 \pm 0.094^{\mathrm{ab}} \\
(0.000-0.003) \\
0.034 \pm 0.003\end{array}$ \\
\hline $\begin{array}{c}\text { 2-Naphthol } \\
\text { ( } \mu \mathrm{mol} / \mathrm{mol} \text { creatinine) }\end{array}$ & $\begin{array}{r}\mathrm{AM} \pm \mathrm{ASD} \\
\text { (Range) } \\
\mathrm{GM} \pm \mathrm{GSD}\end{array}$ & $\begin{array}{c}5.894 \pm 468.3^{b c} \\
(0.846-20.883) \\
4.208 \pm 0.002\end{array}$ & $\begin{array}{l}8.947 \pm 5.931^{\mathrm{ac}} \\
(0.000-23.222) \\
7.484 \pm 0.002\end{array}$ & $\begin{array}{l}1.924 \pm 3.441^{\mathrm{ab}} \\
(0.000-17.794) \\
0.236 \pm 0.023\end{array}$ \\
\hline
\end{tabular}

a: Significantly different from automobile emission inspection workers by Duncan test and ANOVA $(P<0.001)$, b: Significantly different from waste incineration workers by Duncan test and ANOVA $(P<0.001)$, c: Significantly different from controls by Duncan test and ANOVA $(P<$ $0.001)$

phthol than did the automobile emission inspection workers.

\section{Analysis of PAHs and dioxin in air}

The air concentration of total PAHs ranged from 134 to $9,201 \mathrm{ng} / \mathrm{m}^{3}\left(1,692 \pm 1,663 \mathrm{ng} / \mathrm{m}^{3}\right)$ and from 1684 to $9,642 \mathrm{ng} / \mathrm{m}^{3}\left(6,060 \pm 4,011 \mathrm{ng} / \mathrm{m}^{3}\right)$ in automobile emission inspection offices and a waste incineration company, respectively (Table 3 ). The concentration of carcinogenic PAHs in waste incineration work sites was 10 times higher than those levels found in the automobile emission inspection offices.

The concentration of dioxin in air at the waste incinerating company was $31.17 \pm 51.36(0.299-90.45)$ $\mathrm{nq}-\mathrm{TEQ} / \mathrm{Sm}^{3}$ and this was 100 times higher than that found in Seoul and showed the variability between individuals and times of collection as a measure of QA/QC.

\section{DNA damage analysis}

Comet assays were carried out to evaluate the DNA damage in mononuclear and polynuclear cells. In the mononuclear cells, DNA damage for automobile emission inspectors, waste incineration workers and control subjects were $1.71 \pm 0.23,2.23 \pm 0.24$ and 1.34 \pm 0.16 , respectively $(P<0.0001)$ (Table 4). Significant difference in Olive tail moment in mononuclear cells were observed between automobile emission inspection and waste incineration workers and control subjects.

The DNA damage of the polynuclear cells was greater than that in the mononuclear cells. The tail 
Table 3. PAHs composition by IARC classification

\begin{tabular}{|c|c|c|c|c|c|c|c|}
\hline & \multicolumn{4}{|c|}{$\begin{array}{l}\text { Automobile emission inspection workers } \\
\qquad(n=46)\end{array}$} & \multicolumn{3}{|c|}{$\begin{array}{l}\text { Waste incineration workers } \\
\qquad(n=6)\end{array}$} \\
\hline & $\mathrm{RA} \pm \mathrm{SD}(\%)$ & Range $\left(\mathrm{ng} / \mathrm{m}^{3}\right)$ & Mean $\pm S D$ & $\left(\mathrm{ng} / \mathrm{m}^{3}\right)$ & $\mathrm{RA} \pm \mathrm{SD} \quad(\%)$ & Range $\left(\mathrm{ng} / \mathrm{m}^{3}\right)$ & Mean \pm SD $\quad\left(\mathrm{ng} / \mathrm{m}^{3}\right)$ \\
\hline Others & $92.41 \pm 9.77$ & $128.34-8792.64$ & $1692.86 \pm$ & 1663.13 & $85.12 \pm 8.23$ & 1526.33-8388.82 & $5375.13 \pm 3933.83$ \\
\hline Group 3 & $3.98 \pm 4.91$ & $5.38-202.51$ & $42.08 \pm$ & 35.81 & $7.01 \pm 4.34$ & $108.52-746.26$ & $40.39 \pm 321.43$ \\
\hline Group 2B & $1.72 \pm 2.10$ & $0.00-\quad 47.00$ & $18.52 \pm$ & 12.41 & $2.52 \pm 0.95$ & $36.39-226.39$ & $156.95 \pm 104.80$ \\
\hline Group $2 A$ & $1.89 \pm 4.16$ & $0.00-158.68$ & $15.51 \pm$ & 25.06 & $5.36 \pm 7.87$ & $12.86-281.35$ & $130.16 \pm 137.42$ \\
\hline Total & 100 & $134-9201$ & $1962 \pm$ & \pm 1663 & 100 & $1684-9642$ & $6060 \pm 4011$ \\
\hline
\end{tabular}

Group 2A: Probably carcinogenic to humans; benzo(a)anthrancene, benzo(a)pyrene, dibenzo(a,h)anthrancene, Group 2B: Possibly carcinogenic to humans; benzo(b)fluoranthene, benzo(k)fluoranthene, indenol(1,2,3-cd)pyrene, Group 3: Unclassifiable as to carcinogenicity to humans; anthracene, fluoranthene, fluorene, pyrene, chrysene, benzo(g,h,i)perylene, Others: Not included to groups; naphthalene, acenaphthylene, acenephthene

\section{Control}

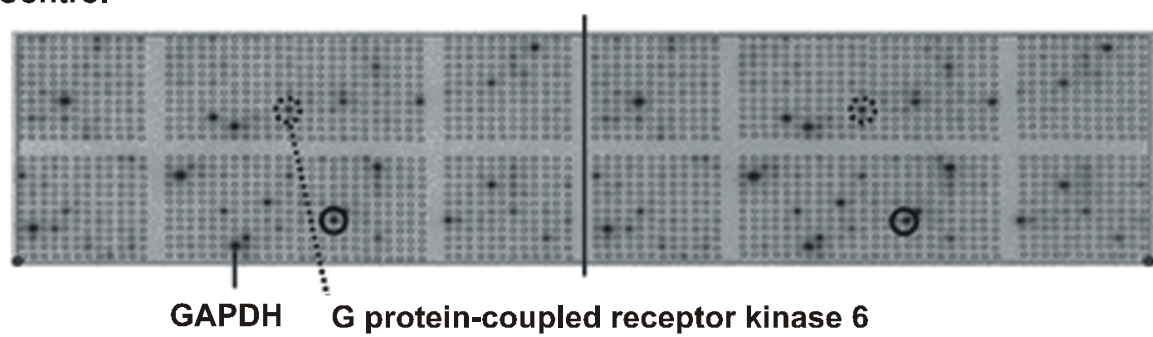

Figure 1. Representative cDNA microarrays of two independent hybridization experiments comparing cDNAs generated from controls (up) or from waste incinerating workers exposed to

Waste incinerating workers

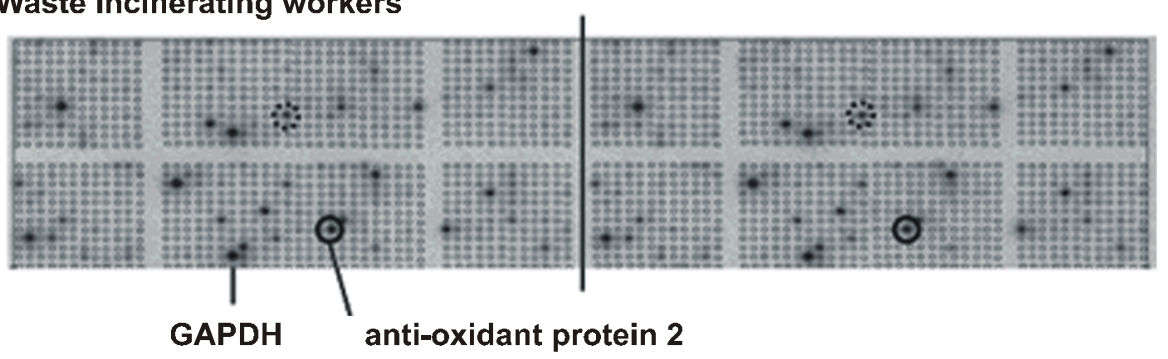
PAH and dioxins (down). CDNA microarray contained 1,152 genes and printed in duplicate (as indicated by the line) and each duplicate is composed of eight individual subarrays. For example, two genes differentially expressed between controls and waste incineration workers are marked by circles (solid circle, anti-oxidant protein 2; dotted circle, $G$ protein-coupled receptor kinase 6; no circle, GAPDH).

moments of polynuclear cells in automobile emission inspectors, waste incineration workers and control subjects were $2.85 \pm 0.49,3.32 \pm 0.38$ and $2.72 \pm$ 0.59 respectively. No significant difference in Olive tail moments of polynuclear cells was observed between automobile emission inspection workers and control subjects, but a slight increase in the Olive tail moments of the polynuclear cells for waste incineration workers was found versus the control subjects (Table 3).

The DNA damage comparison between exposed workers and control subjects showed that mononuclear cells are very sensitive cells to PAHs exposure.

\section{Gene expression profiles in workers exposed to PAHs or dioxin}

Radioactive hybridization was visualized by phosphoimaging technologies. The primary image, that is the results of primary capture by the phosphoimager, is shown in Figure 1. This particular array was printed in duplicate (as indicated by the line) and each duplicate was composed of eight individual subarrays. A visual inspection of the hybridization patterns readily identified a number of signals differentially expressed between the controls and the automobile emission inspectors (or waste incineration workers). An analysis of the median densitometric signal intensity revealed that 11 genes increased and 4 genes decreased when compared with waste incineration worker and the controls by a Z-ratio of 2 at a descriptive $P \leq 0.05$. We marked three genes: two 
Table 4. DNA damage in mono- and polynuclear cells in automobile emission inspection workers, waste incineration workers and control subjects.

\begin{tabular}{|c|c|c|c|}
\hline \multirow{2}{*}{ Cell Type } & \multicolumn{3}{|c|}{ Olive tail moment } \\
\hline & $\begin{array}{l}\text { Automobile emission inspection } \\
\text { workers }(n=44)\end{array}$ & $\begin{array}{l}\text { Waste incineration workers } \\
\qquad(n=31)\end{array}$ & $\begin{array}{l}\text { Control subjects } \\
\qquad(\mathrm{n}=84)\end{array}$ \\
\hline Mononuclear & $1.71 \pm 0.23^{\mathrm{bc}}$ & $2.23 \pm 0.54^{\mathrm{ac}}$ & $1.34 \pm 0.16^{\mathrm{ab}}$ \\
\hline Polynuclear & $2.85 \pm 0.49^{b c}$ & $3.32 \pm 0.38^{\mathrm{ac}}$ & $2.72 \pm 0.59^{\mathrm{a}}$ \\
\hline
\end{tabular}

a: Significantly different from automobile emission inspection workers by Duncan test and ANOVA $(P<0.001)$, b: Significantly different from waste incineration workers by Duncan test and ANOVA $(P<0.001)$, c: Significantly different from controls by Duncan test and ANOVA ( $P<$ 0.001)

Table 5. Up- and down-regulated gene expression in automobile emission inspectors and waste incineration workers by cDNA microarray.

\begin{tabular}{|c|c|c|c|}
\hline & \multirow{2}{*}{ Gene name } & \multicolumn{2}{|c|}{ Z ratio } \\
\hline & & $\begin{array}{c}\text { Automobile emission } \\
\text { inspectors }\end{array}$ & $\begin{array}{c}\text { Waste incinerating } \\
\text { workers }\end{array}$ \\
\hline \multirow[t]{11}{*}{ Increase } & Integrin-linked kinase (ILK) mRNA, complete cds & 1.48 & 2.43 \\
\hline & KIAA0380 gene, complete cds & 1.54 & 2.42 \\
\hline & Cytochrome P450 IIF1 (CYP2F1) & 0.52 & 2.40 \\
\hline & Cytochrome P450 IID6 (CYP2D6) & 1.43 & 2.32 \\
\hline & Mitochondrial cytochrome $P 450 \times 1 A 1$ precursor & 0.76 & 2.23 \\
\hline & Phosphoenolpyruvate carboxykinase 1 (soluble) & 0.80 & 2.15 \\
\hline & Anti-oxidant protein 2 & 1.65 & 2.15 \\
\hline & Casein kinase I gamma 2 mRNA, complete cds & 0.80 & 2.08 \\
\hline & Glutathione S-transferase M1 & 1.74 & 2.06 \\
\hline & Interleukin-1 receptor-associated kinase (IRAK) Mrna & 0.17 & 2.03 \\
\hline & Glutathione peroxidase 4 (phospholipid hydro-peroxidase) & 1.37 & 2.02 \\
\hline \multirow[t]{4}{*}{ Decrease } & G protein-coupled receptor kinase 6 & 0.04 & -2.05 \\
\hline & ESTs, highly similar to guanylate kinase & -0.71 & -2.07 \\
\hline & CNCG & -1.81 & -2.38 \\
\hline & ESTs, weeklv similar to C16 C10.5 & -1.27 & -3.33 \\
\hline
\end{tabular}

1) Z-value (gene1) $=\log 10$ [raw intensity (gene1)] - $\log 10$ [mean raw intensity (all genes)]/standard deviation $\log 10$ [raw intensity (all genes)], 2) Z-difference (gene1) = Z(gene1,array1) - Z(gene1,array2), 3) Z-ratio (gene1) = Z-difference(gene1) / Sdev(Z-difference all genes), The numbers of samples in the cDNA microarray in automobile emission inspection workers, waste incineration workers and control subjects were 44,31 , and 42 , respectively.

of these genes were expressed differently in waste incinerating workers and controls (Anti-oxidant protein 2, G protein-coupled receptor kinase 6 ) and one gene similarly expressed between the waste incineration workers and the controls (GAPDH). Gene expression profiles of interest were significantly up-regulated (11 genes) or down-regulated (4 genes) in waste incineration workers when compared with the controls. The prominently changed genes are listed in Table 5. The genes showing highly altered expression levels were aligned in the order of the magnitude of their altered expression in automobile emission inspectors and waste incineration workers exposed to polycyclic aromatic hydrocarbons or 2,3,7,8,-Tetracholrodedibenzo-p-dioxins. It is interesting that genes related to oxidative stress were up regulated in waste incinerat- ing workers. Comparison rank analysis revealed that the expression of five genes related to oxidative stress, including CYP2F1, CYP2D6, anti-oxidant protein 2, glutathione S-transferase $M 1$, and glutathione peroxidase 4 increased by more than 2.02 of the Z-ratio (Table 5). Other genes up-regulated in waste incinerating workers are integrin-linked kinase, casein kinase 1 , etc. which are known to be involved in general cell signaling pathway

Figure 2 is Scatter plot for comparing the expression profiles of waste incineration workers and the controls. Expression profiles of the blood for waste incinerating workers and the control subjects are shown as a scatter plot of 1,152 genes from the microarray. A regression analysis of $Z$ scores from two independent samples of the waste incineration 


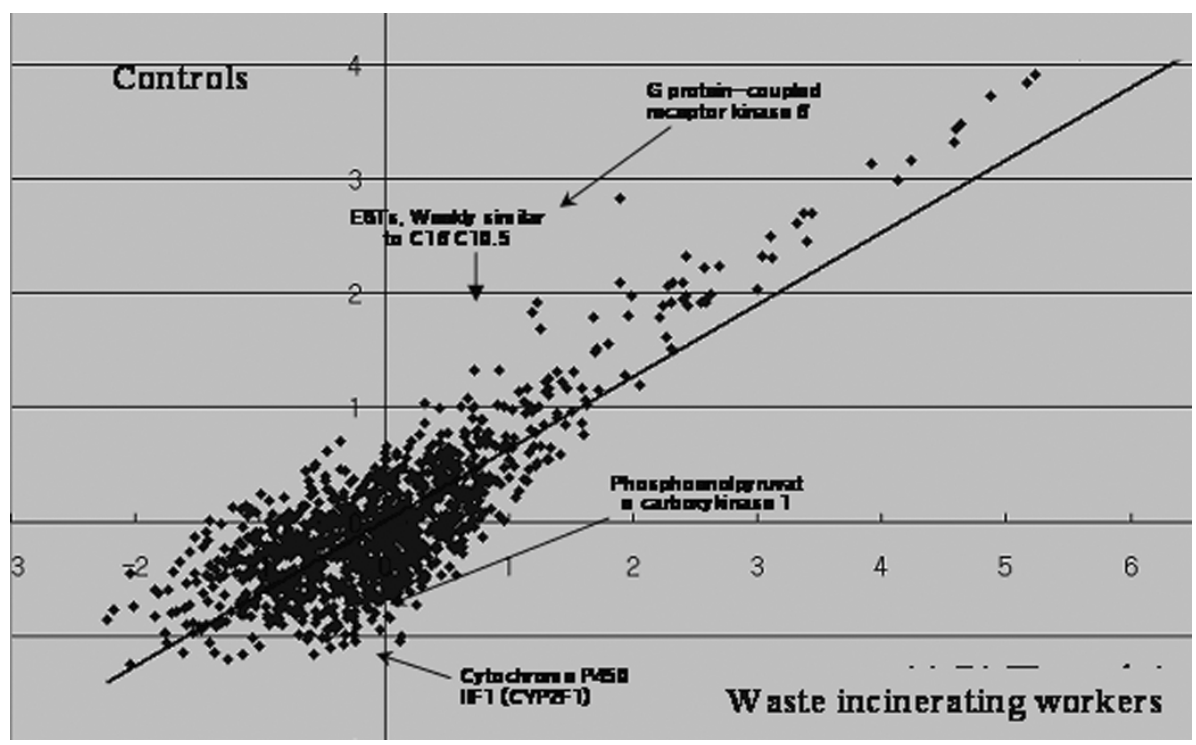

Figure 2. Scatter plot for comparison of expression profile between controls and waste incineration workers. Expression profiles of the bloods in controls and waste incineration workers exposed to PAH and dioxins are shown as scatter plot of 1,152 genes from the microarray. The values are corrected intensities relative to controls, representing levels of expression for the cDNA elements of the microarrays.

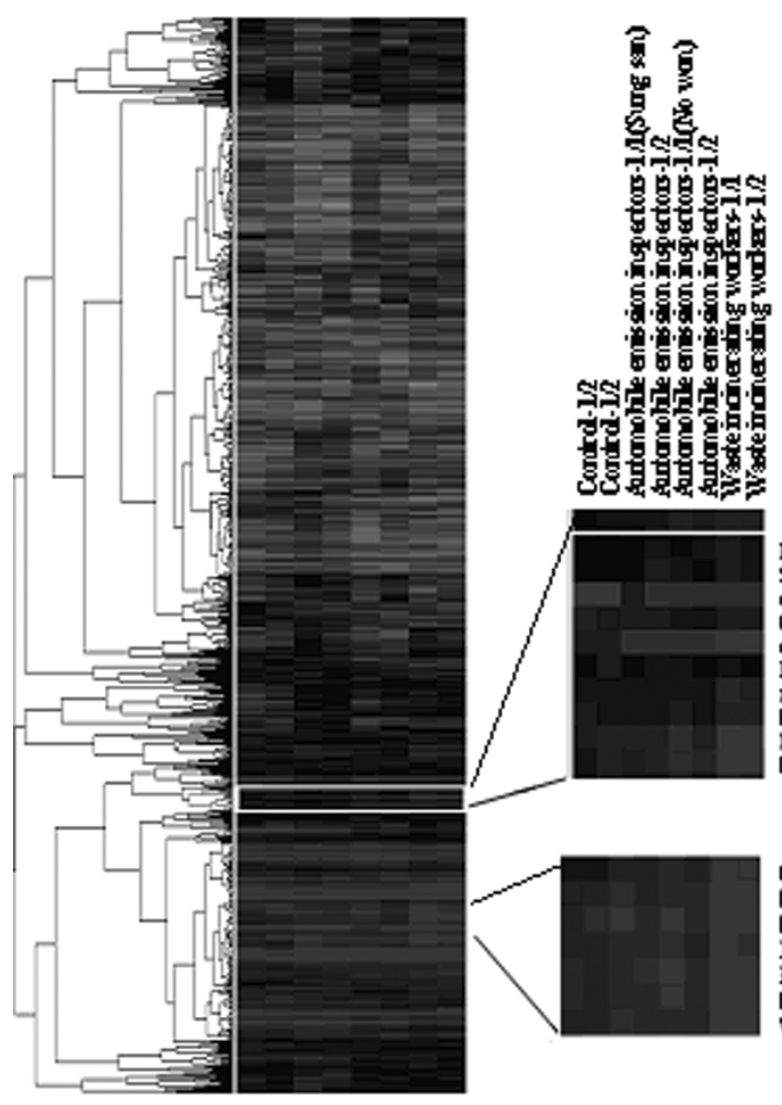

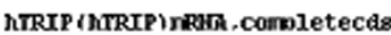

So3transcrintion factor

GlutathioneS-trans ferasek (brain)

cvtochrome P450 VIIA1 (CXP7R1)

Proteinkinasec carma

rmoras-relateitorotetn

kTaro311arene, partialce

Protei mososphatise 2 ( tormer1 Y2R), regulatorysubund tB (PR52) .

Deoxvthvidivlatekinase

GutathioneS-transferaseM1

ESTs . Neakl vsinilartoenidermalarowthfact orreceptorkine

Recrulat orof $\mathrm{G}$-proteinsicmallina1

Inositol1.4.5-triswhoswhate 3-kinase

Acionhognhatase 5 , tartrateresistant

KInf0387enene, vartialcils

V-erb-b2avianervthroblasticleukemdaviralonconenerono]

Figure 3. Clustergram of up and down regulated gene expression in controls, automobile emission inspectors and waste incineration workers. Microarray data from the bloods of controls and workers exposed to PAH and dioxins were combined and clustered. Cluster analysis was performed on Z-transformed microarray data by using two separate programs available as share ware from Michael Eisens lab. Each gene is represented by a single row of colored boxes; each experimental sample represented by a single column. The entire clustered image is shown on the left. These clusters contain uncharacterized genes that are not involved in these processes. 
workers and the controls were performed, and the $Z$ scores of individual genes were plotted.

To obtain a molecular portrait of those genes exposed to polycyclic aromatic hydrocarbons or 2,3 , $7,8,-$ Tetracholrodedibenzo-p-dioxins, we used a hierarchical clustering algorithm to group genes on the basis of their similar expression patterns (Eisen et al., 1998), and the data are presented in a matrix format (Figure 3 ). Each row of Figure 3 represents all the hybridization results for a single DNA element of the array, and each column represents the expression levels for all genes in a single hybridization sample. The expression level of each gene was visualized in color, relative to its median expression level across all samples. Red represented an expression greater than the mean, green represents an expression less than the mean, and color intensity denotes the degree of deviation from the mean. Gray represented a median expression level. Distinct samples representing similar gene patterns from the control cells were

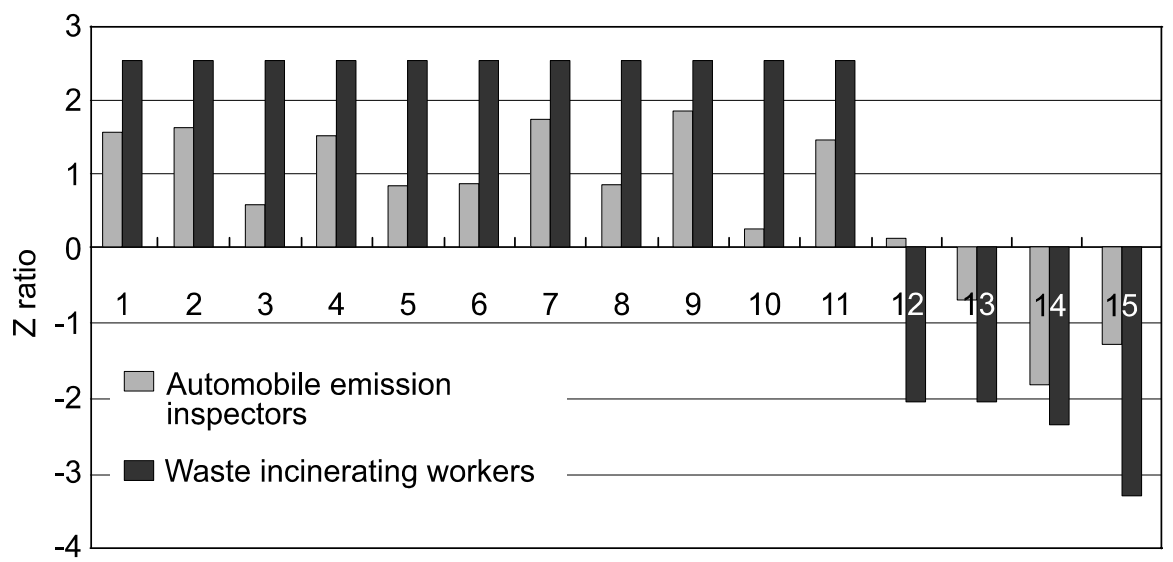

Figure 4. Comparison of Z-ratio in automobile emission inspectors and waste incineration workers. 1. Integrin-linked kinase (ILK) mRNA, complete cd, 2.KIAA0380 gene, complete cds 3. Cytochrome P450 IIF1 (CYP2F1), 4. Cytochrome P450 IID6 (CYP2D6), 5. Mitochondrial cytochrome P450 X1A1 precursor, 6. Phosphoenolpyruvate carboxykinase 1 (soluble), 7. Anti-oxidant protein 2, 8. Casein kinase I gamma 2 mRNA, complete cds, 9. Glutathione S-transferase M1, 10. Interleukin-1 receptor-associated kinase (IRAK) Mrna, 11. Glutathione peroxidase 4 (phospholipid hydroperoxidase), 12. G protein-coupled receptor kinase 6,13 . ESTs, highly similar to guanylate kinase, 14. CNCG, 15. ESTs, weekly similar to C16 C10.5.

Table 6. Up and down regulated proteins in plasma between automobile emission inspectors and waste incineration workers.

\begin{tabular}{|c|c|c|c|c|c|}
\hline & $\begin{array}{l}\text { Automobile } \\
\text { emission } \\
\text { inspectors }\end{array}$ & $\begin{array}{l}\text { Waste } \\
\text { incineration } \\
\text { workers }\end{array}$ & $\begin{array}{l}\text { Estimated } \\
\mathrm{Mr}(\mathrm{KDa}) / \mathrm{pl}\end{array}$ & Coverage $(\%)$ & $\begin{array}{c}\text { Accession no. } \\
\text { (SWISS-PROT } \\
\text { TrEMBL) }\end{array}$ \\
\hline \multirow[t]{8}{*}{ Increase } & Complement C4 & Complement C4 & $32 / 6.4$ & 25 & P01028 \\
\hline & Transthyretin & Transthyretin & $35 / 5.5$ & 55 & P02766 \\
\hline & Sarcolectin & Sarcolectin & $51 / 5.6$ & 17 & P08729 \\
\hline & \multirow{5}{*}{$\begin{array}{c}\text { Complement factor B } \\
\text { Serotransferrin } \\
\text { HDJ2protein } \\
\text { Fibrinogen } \alpha / \\
\alpha-E \text { chain }\end{array}$} & & $102 / 6.1$ & 25 & P00751 \\
\hline & & & $92 / 6.2$ & 21 & P02787 \\
\hline & & & $29 / 5.6$ & 20 & Q9NXZ8 \\
\hline & & $64 / 7.0$ & 14 & P02671 & \\
\hline & & $\begin{array}{l}\text { Serum araoxonase/ } \\
\text { arvlesterase }\end{array}$ & $43 / 4.9$ & 21 & P27169 \\
\hline Decrease & Haptoqlobin-1 & Haptoqlobin-1 & $35 / 5.8$ & 13 & P00731 \\
\hline
\end{tabular}

The numbers of samples in the proteomic analysis in automobile emission inspection workers, waste incineration workers and control subjects were 44,31 , and 42 , respectively. 
aligned in adjacent rows. The clustergram revealed that clusters of genes related to oxidative stress were up-regulated in waste incineration workers, as compared to controls (Figure 4).

\section{Proteomic analysis}

Figure 5 shows the 2-DE pattern with $\mathrm{pH} 3-10 \mathrm{NL}$ IPG Dry strip and the changes of 9 up-or down regulated plasma proteins in the automobile emission inspectors and waste incineration workers (Table 6

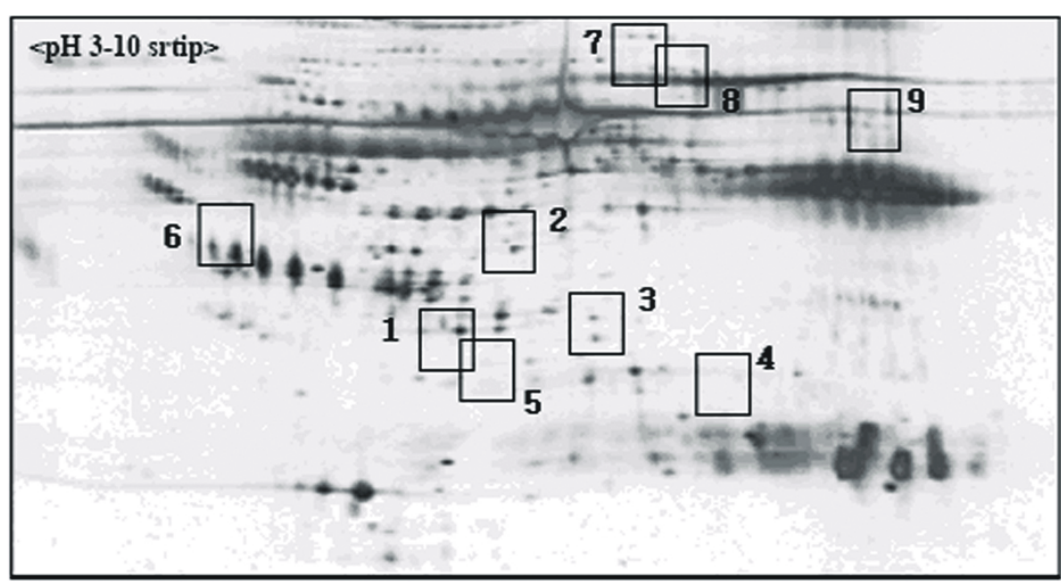

Control subject

\section{Transthyretin}

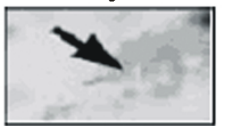

\section{Sarcoletin}

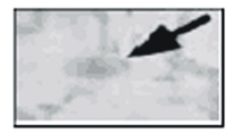

3. Haptoglobin-1

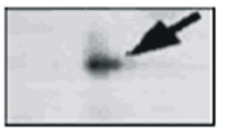

4. Complement C4

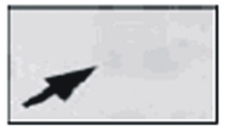

5. HDJ2 protein

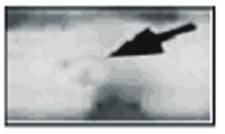

6. Serum araoxonase larylesterase

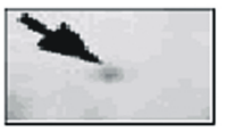

7. Complement factor B

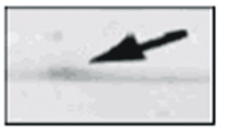

\section{Serotransferrin}

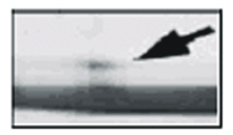

9. Fibrinogen $\alpha$ I $\alpha-E$ chain
Automobile Waste incinerating
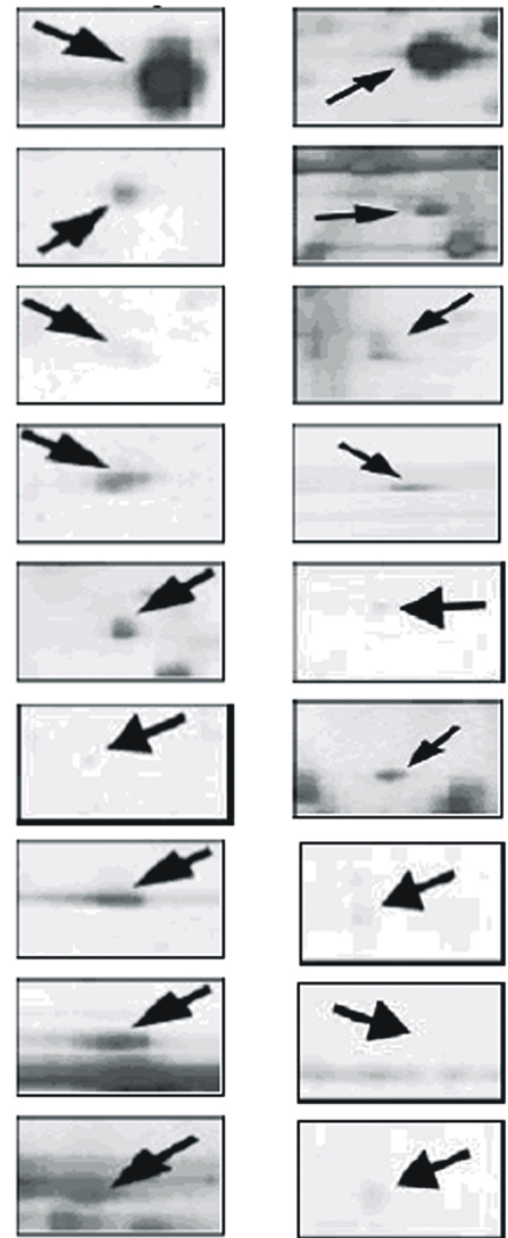
emission inspectors workers

Figure 5. Protein expression in automobile emission inspectors and waste incineration workers. The 2-DE pattern of plasma proteins and nine spots which were up- or down-regulated in automobile emission inspectors and waste incineration workers. 


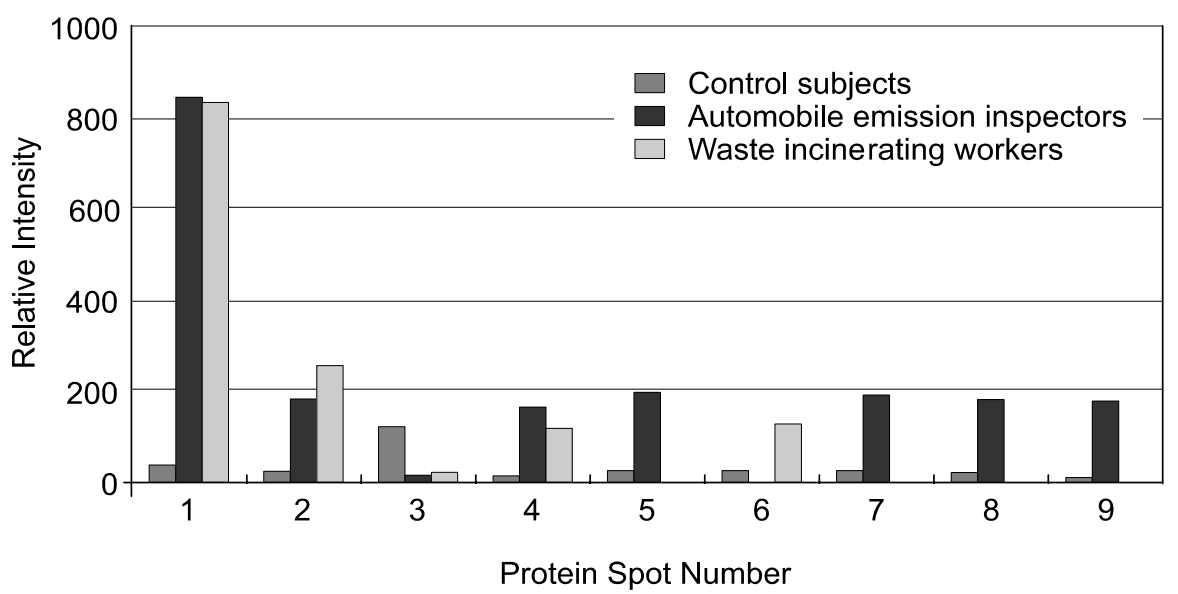

Figure 6 . Relative intensity of up- or down-regulated proteins in automobile emission inspectors and waste incineration workers. The spot volumes were analyzed by total spot normalization and each spot quantity. Each bar represents the mean of relative intensity of each spot. and Figure 5). The increases or decreases in the plasma protein expression in both subjects were statistically significant. Eight plasma proteins were up-regulated and five plasma proteins were downregulated and five plasma proteins were in automobile emission inspectors and waste incineration workers, respectively (Figure 5 and 6 ). Complement $\mathrm{C} 4$, transthyretin and sarcolectin were up-regulated in both automobile emission inspectors and the waste incineration workers. Fibrinogen $\alpha / \alpha-E$ chain, serotransferin, complement factor $\mathrm{B}$, and $\mathrm{HDJ} 2$ protein were up regulated in automobile emission inspectors, but not in the waste incinerating workers. Haptoglobin-1 was significantly down-regulated in both subjects. Among the 9 plasma proteins, transthyretin was the most prominently expressed spot (Figure 6) for the automobile emission inspectors and waste incineration workers.

\section{Discussion}

In the past decade, several biomarkers have been used for the assessment of human exposure to PAHs. Among these, urinary metabolites 1-OHP and 2-naphthol have served as good biomonitoring markers (Jongeneelen et al, 1985; Kim et al., 1999). In our present study, the urinary 1-OHP and 2-naphthol concentration in both subjects were found to be similar to those in aircraft maintenance and shipyard workers (Kim et al., 2001; Lee et al., 2001).

PAHs were classified by three different groups which show different level of carcinogenicity (IARC). Air concentrations of three different groups of PAHs were similar in the automobile emission inspection offices and the waste incineration company, but the DNA damage in mononuclear cells of both subjects showed a significant difference. The difference of DNA damage between the two exposed subjects could be caused by the effects of dioxins in waste incineration company.

The microarray-based genomic survey is a highthroughput approach, that allows parallel study on the expression patterns of thousands of genes (Konu et al., 2001). This technique can identify the correlation of gene expression pattern and environmental contamination by performing comparison-rank analysis of genes expressed by the transcription of DNAs into RNAs. In this study, we discovered novel evidence for previously unknown gene expression patterns related to oxidative stress in workers exposed to $\mathrm{PAH}$ or Dioxin; e.g., CYP2F1, CYP2D6, anti-oxidant protein 2, glutathione S-transferase $\mathrm{M} 1$, and glutathione peroxidase 4.

Oxidative stress is the biochemical modification of cells, tissues and lipids due to their interactions with free radicals. Interactions can increase, decrease or alter the function of specific proteins, and this depends on the degree and type of protein modification. Free radicals are highly unstable molecules that interact quickly and aggressively with other molecules in our bodies to create abnormal cells (Kim et al., 2003). They are capable of penetrating into and damaging the DNA of a cell so the cell will produce mutated cells that can replicate out of control. Cellular defenses against oxidants are antioxidant enzymes (such as catalase, superoxide dismutase, and peroxidases.) and antioxidant molecules (such as glutathione, vitamin $C$, and vitamin $E$ ). In this study, we describe the up regulation of anti-oxidant protein 2, glutathione $S$ transferase $\mathrm{M} 1$, and glutathione peroxidase 4 , which are well known proteins that protect against oxidative damage. The observed induction of several genes, and especially those of the antioxidative enzymes, is undoubtedly a result of the cellular efforts to protect itself against the effects of cell oxidation. These detoxification conditions have been shown to enhance the expression of several 
anti-oxidant enzymes that shift to anti-oxidation status in a free radical metabolism that is typical of oxidative stress.

In the proteomic analysis, we found 9 significant proteins whose expressions were down- or up regulated (Table 8). Immune related proteins, complement 4 and complement factor $B$ were up-regulated in both the automobile emission inspectors and waste incineration workers. Complement 4 and complement $B$ act as effectors in immune defense system. Complement 4 increases vascular pexdcrmeability and causes histamine release from mast cells and basophilic leukocytes.

Haptoglobin combines with free oxyhemoglobin to form a stable complex that has a weak peroxidase activity. Paraoxonase/arylesterase plays the roles of antioxidants to protect lipid peroxidation in the cell membrane. However, these two plasma proteins that could be involved in the peroxidation process showed a different expression in each exposed subjects. Haptoglobin was decreased in both exposed subjects but paraoxonase/arylesterase was increased only in waste incineration workers. In an animal study, lipid peroxidation was enhanced by exposure of $2,3,7$, 8-TCDD (Wahba et al., 1989; Pohjanvirta et al., 1990). In a human population study, graphite ware production and steel industry workers exposed to $\mathrm{PAHs}$ revealed the changes in the state of the monooxigenase system and lipid peroxidation (Haguenoer et al., 1996).

Serotransferrin, which is called "the plasma transferring protein", is a glycoprotein that has metal binding properties and it usually transports iron into cells through the transferring receptors. The expression of serotransferrin was up-regulated only in the automobile emission inspectors. In the environment, an important source of heavy metals is the combustion of leaded gasoline used for transportation (Falahi-Ardakani, 1984), and a street deposit sampling showed the contamination of heavy metals and hydrocarbons (Bris et al., 1999).

Sarcolectin is one of lectins and nonspecific stimulators of cellular DNA synthesis that was found in all animal sera (Kaba et al., 2000; Kaba et al., 2002) and it may play the role of recovery to DNA damage caused by PAHs or dioxins in both exposed subjects.

HDJ2 protein is one of heat shock protein 40 (Hsp40), and it plays the important roles of intracellular activation through the activation of $\mathrm{Hsp} 70$. Hsp70 has been served as a biomonitoring marker for ecotoxicological studies (Pyza et al., 1997). A strong induction of Hsp 70 was observed under exposure of pollutants, metals and various stresses (Urani et al., 2001; Lee et al., 2002; Sofia et al., 2002) in Baikalian sponges, HepG2 cell lines and murine embrio fibroblast cells, respectively. However,
HDJ2 protein was up-regulated only in automobile emission inspectors.

In addition, Transthyrethin, which is called prealbumin, has a role for carrying various materials into from the liver to different tissues and it was significantly over expressed in automobile emission inspectors and waste incineration workers $(20$ and 30 folds, respectively) (Figure 5). With its significant high expression in exposed subjects, transthyretin could be a useful biomontoring markers in human exposed to PAHs or dioxins. However, no evidence was found as to why transthyretin was up-regulated in plasma, and further experimentation using vitro or vivo studies will be needed to find out the specific role of transthyrethin.

The difference between the results of cDNA microarray study and those of 2-DE gel electrophoresis study may be come from the difference of target tissue. The results of cDNA microarray and proteomic studies were obtained from the blood cells and plasma proteins, respectively and almost plasma proteins are released mainly from the liver. Even though some proteins are released into plasma from blood cells with previous change of gene expression by toxic compounds, their amounts may be not significant enough to change proteome in plasma. In addition, the smoking effects were evaluated, but significant differences were not found in cDNA microarray and proteomic studies.

In summary, our study shows that genes and proteins involved in oxidative stress were up-regulated in both automobile emission inspectors and the waste incinerating workers exposed to PAHs or dioxins. Several proteins, such as transthyrethin, sarcolectin and haptoglobin, that were highly up- or down-regulated, could serve as biological monitoring markers

\section{Acknowledgment}

This work was supported by the Korea Food and Drug Administration grant and by the Medical Research Center for Environmental Toxico-Genomics \& Proteomics of Korea University. We thank Dr. Yoon S. Cho-Chung (Cellular Biochemistry Section, Basic Research Laboratory, CCR, NCI, NIH, Bethesda, MD) and Dr. Kevin G. Becker (DNA Array Unit, NIA, NIH, Baltimore, MD) for valuable advices on cDNA microarray.

\section{References}

Albertini RJ. The use and interpretation of biomarkers of environmental genotoxicity in humans. Biotherapy 1998;11: 155-67

Birnbaum LS, Fenton SE. Cancer and developmental exposure to endocrine disruptors. Environ Health Perspect 


\section{3:111:389-94}

Birnbaum LS, Staskal DF, Diliberto JJ. Health effects of polybrominated dibenzo-p-dioxins (PBDDs) and dibenzofurans (PBDFs). Environ Intern 2003;29:855-60

Brandt HC, Watson WP. Monitoring human occupational and environmental exposures to polycyclic aromatic compounds. Ann Occupation Hygiene 2003;47:349-78

Bris FJ, Garnaud S, Apperry N, Gonzalez A, Mouchel JM, Chebbo G, Thevenot DR. A street deposit sampling method for metal and hydrocarbon contamination assessment. SciTotal Environ 1999;235:211-20

Burchiel SW. The effects of environmental and other chemicals on the human immune system: the emergence of immunotoxicology. Clin Immunol 1999;90:285-6

Chhabra RS, Bucher JR, Wolfe M, Portier C. Toxicity characterization of environmental chemicals by the US National Toxicology Program: an overview. Intern J Hyg \& Environ Health 2003;206:437-45

Claudio L, Kwa WC, Russell AL, Wallinga D. Testing methods for developmental neurotoxicity of environmental chemicals. Toxicol Appl Pharmacol 2000;164:1-14

DeRisi J. Penland L. Brown PO, Bittner ML, Meltzer PS. Ray, Chen Y, Su YA, Trent HM. Use of a cDNA microarray to analyse gene expression patterns in human cancer Nat Genet 1996;14:457-60

Diaz-Sanchez D. The role of diesel exhaust particles and their associated polyaromatic hydrocarbons in the induction of allergic airway disease. Allergy 1997;52:52-6

Eisen MB, Spellman PT, Brown PO, Botstein D. Cluster analysis and display of genome-wide expression patterns. Proc Natl Acad Sci USA 1998;95:14863-8

Efremova SM, Margulis BA, Guzhova IV, Itskovich VB, Lauenroth S, Muller WEG, Schroder HC. Heat shock protein Hsp70 expression and DNA damage in baikalian sponges exposed to model pollutants and waste from baikalsk pulp and paper plant. Aquatic Toxicol 2002;57:267-80

Everaert K, Baeyens J. The formation and emission of dioxins in large scale thermal processes. Chemosphere 2002; 46:439-48

Falahi-Ardakani A. Contamination of environment with heavy metals emitted from automotives. Ecotoxicol Environ Safety $1984 ; 8: 152-61$

Haguenoer JM, Shirali $P$, Hannothiaux MH, Nisse-Ramond C. Interactive effects of polycyclic aromatic hydrocarbons and iron oxides particles. Central Eur J Pub Health 1996;4:41-5

Hays SM, Aylward LL. Dioxin risks in perspective: past, present, and future. Regulat Toxicol Pharmacol 2003;37:20217

Hosokawa Y, Yasui M, Yoshikawa K, Tanaka Y. Suzuki M. The nationwide investigation of endocrine disruptors in sediment of harbours. Marine Pollut Bull 2003;47:132-8

Jongeneelen FJ, Anzion RBM, Leijdekkers CM, Bos RP, Henderson PT. 1-Hydroxy-pyrene in human urine after exposure to coal tar and a coal tar derived product. Int Arch Occup Environ Health 1985;57:47-55
Joo W-A, Kang M-J, Son W-K, Lee D-Y, Lee E, Kim C-W. Monitoring protein expression by proteomics: Human plasma exposed to benzene. Proteomics 2003;3:2402-11

Kaba A, llunga LA, Chany C. Role of sarcolectin (SCL) and interferons in coordinated $\mathrm{T}$ cell clonal expansion. J Interf Cyto Res 2000;20:519-25

Kaba A, llunga LA, Achour A, Zagury JF, Chany C. The interferon antagonist sarcolectin in the progress of HIV-1 infection and AIDS. J Interf Cyto Res 2002;22:305-10

Kim H, Lee Y-D, Lee H, Kawamoto T, Yang M, Katoh T. Assay of 2-naphthol in human urine by high-performance liquid chromatography. J Chromatogr B Biomed Appl 1999; 734:211-7

Kim H, Cho S-H, Kang J-W, Kim Y-D, Nam H-M, Lee C-H, Lee H, Kawamoto T. Urinary 1-hydroxypyrene and 2-naphthol concentration in male Koreans. Int Arch Occup Environ Health 2001;74:59-62

Kim YH, Lee JH, Lim do S, Shim WJ, Ro YM, Park GH, Becker KG, Cho-Chung YS, Kim MK. Gene expression profiling of oxidative stress on atrial fibrillation in humans. Exp Mol Med 2003;35:336-49.

Kogevinas M. Human health effects of dioxins: cancer, reproductive and endocrine system effects. Human Reprod Update $2001 ; 7: 331-9$

Konu, O, Kane JK, Barrett T, Vawter MP, Chang R, Ma JZ, Donovan DM, Sharp B, Becker KG, Li MD. Region-specific transcriptional response to chronic nicotine in rat brain. Brain Res 2001;909:194-203.

Kress S, Greenlee W. Cell-specific regulation of human CYP1A1 and CYP1B1 genes. Cancer Res 1997;57:1264-9

Kumagai S, Koda S, Oda $\mathrm{H}$. Exposure evaluation of dioxins in municipal waste incinerator workers. Indust Health 2003; 41:167-74

Lee C-Y, Lee J-Y, Kang J-W, Kim H. Effects of genetic polymorphisms of CYP1A1, CYP2E1, GSTM1, and GSTT1 on the urinary levels of 1-hydroxypyrene and 2-naphthol in aircraft maintenance workers. Toxicol Lett 2001;123:115-24.

Lee J-S, Seo J-S. Differential expression of two stressinducible hsp70 genes by various stressors. Exp Mol Med 2002;34:131-6

Mann KK, Matulka RA, Hahn ME, Trombino AF, Lawrence $\mathrm{BP}$, Kerkvliet NI, Sherr DH. The role of polycyclic aromatic hydrocarbon metabolism in dimethylbenz(a) anthracene-induced pre-B lymphocyte apoptosis. Toxicol Appl Phamacol 1999:161:10-22

Melendez-Colon VJ, Luch A, Seidel A, Baird WM. Cancer initiation by polycyclic aromatic hydrocarbons results from formation of stable DNA adducts rather than apuric sites. Carcinogen 1999;20:1885-91

Möller A, Soldan M, Volker U, Maser E. Two-dimensional gel electrophoresis: a powerful method to elucidate cellular responses to toxic compounds. Toxicol 2002;160:129-38

Oh SM, Ro KS, Chung KH. Induction of cytochrome P4501A and endocrine disrupting effects of school incinerator residues. Environ Monit Assess 2003;83:35-45 
Pohjanvirta R, Sankari S, Kulju T, Naukkarinen A, Ylinen M, Tuomisto J. Studies on the role of lipid peroxidation in the acute toxicity of TCDD in rats. Parmacol Toxicol 1990; 66:339-408

Pyza E, Mak P, Kramarz P, Laskowski R. Heat shock proteins (HSP70) as biomarkers in ecotoxicological studies. Ecotoxicol Environmen Safety 1997;38:244-51

Shugart L, Theodorakis C. New trends in biological monitoring: application of biomarkers to genetic ecotoxicology. Biotherapy 1998;11:119-27

Singh NP, McCoy MT, Tice, RR, Schnider EL. A simple technique for quantification follow levels of DNA damage in individual cells. Exp Cell Res 1988;175:184-91

Son W-K, Lee D-Y, Lee S-H, Joo W-A, Kim C-W. Analysis of proteins expression in rat plasma exposed to dioxin using 2-dimensional gel electrophoresis. Proteomics 2003;3:2393401

Tanaka TS, Jaradat SA, Lim M, Kargul GJ, Wang X, Grahovac MJ, Pantano S, Sano Y, Piao Y, Nagaraja R. Genome-wide expression profiling of mid-gestation placenta and embryo using a 15,000 mouse developmental cDNA microarray. Proc Natl Acad Sci USA 2000;97:9127-32
The International Agency for Research on Cancer (IARC), IARC monographs on the evaluation of the carcinogenic risk of chemicals to humans; polynuclear aromatic compounds, part 1, chemical, environmental and experimental data. 1998;32

Thier R, Golka K, Bruning T, Ko Y, Bolt HM. Genetic susceptibility to environmental toxicants: the interface between human and experimental studies in the development of new toxicological concepts. Toxicol Lett 2002;127:321-7

Urani C, Melchioretto P, Morazzoni C, Canevali C, Camatini M. Copper and zinc uptake and hsp70 expression in HepG2 cells. Toxicol in Vitro 2002;15:497-502

Vawter MP, Barrett T, Cheadle C, Sokolov BP, Wood WH 3rd, Donovan DM, Webster M, Freed WJ, Becker KG. Application of cDNA microarrays to examine gene expression differences in schizophrenia. Brain Res Bull 2001;55:64

Wahba ZZ, Murray WJ, Hassan MQ, Stohs SJ. Comparative effects of pair-feeding and 2,3,7,8-tetrachlorodibenzo-p-dioxin (TCDD) on various biochemical parameters in female rats. Toxicology 1989;59:311-23

Wu C-H, Hsieh C-L, Song T-Y, Yen G-C. Inhibitory effects of Cassia tora $\mathrm{L}$. on Benzo(a)pyrene-mediated DNA damage toward HepG2 cells. J Agric Food Chem 2001;49:2579-86 